\title{
Rancangan dan Penerapan Strategi Pembelajaran pada Mata Kuliah Media dan Teknologi Pembelajaran di Program Studi PAUD Fakultas Psikologi dan Pendidikan Universitas Al Azhar Indonesia
}

\author{
Fidesrinur \\ Program Studi Pendidikan Anak Usia Dini, Fakultas Psikologi dan Pendidikan, \\ Universitas Al Azhar Indonesia, Jl.Sisingamangaraja, Jakarta 12110 \\ E-mail: fideza@uai.ac.id
}

\begin{abstract}
Abstrak - Rancangan dan penerapan strategi pembelajaran pada mata kuliah media dan teknologi pembelajaran merupakan suatu aktivitas latihan proses pembelajaran bagi mahasiswa. Dalam perancangan pembelajaran diperlukan kemampuan mahasiswa dalam merencanakan pembelajaran, pelaksanaan pembelajaran dan evaluasi sebagai sebuah system pembelajaran yang tersebar dalam berbagai mata kuliah. Dalam pelaksanaan aktivitas pembelajaran mahasiswa mengembangkan pembelajaran sesuai dengan pemahamannya terhadap filosofi pembelajaran yang mereka miliki, kemampuannya dalam menstruktur aktivitas sesuai tujuan yang ada dengan mempertimbangkan gaya belajar anak. Efektivitas dan efisiensi pembelajaran merupakan wujud dari pemahaman mahasiswa tentang teori yang diterjemahkan ke dalam praktek pembelajaran dalam bekerjasama dengan sesama mahasiswa dan dosen.
\end{abstract}

Abstract - For the student of Early Childhood Education (ECE) designing and applying learning strategy in Media and Learning Technology subject is the process of teaching and learning activities where they directly experience the teaching ang learning process in the class. In order to be capable for designing learning activitities such as planning, actuating, and evaluating as a learning system, the students also need capabilities in some prerequisite subject. In developing teching and learning process, students caused by their philosophy on teaching, capabilities on structuring activities based on teaching goals regarding students learning style. The effectiveness and the efficiency of the teaching and learning strategy implement is based on students' comprehension on theory and their capabilities in translating it into teaching and learning practice where their friends suppose to be students.

Keywords - learning theory, teaching and learning, learning style, learning system.

\section{PENDAHULUAN}

$\mathrm{T}$ ugas dosen adalah pengajar dan pendidik. Sebagai pendidik dosen bertanggung untuk mencapai tujuan pembelajaran yang telah ditetapkannya, sementara itu sebagai pendidik tanggungjawabnya tidak hanya sekedar tercapai atau tidaknya tujuan pengajaran tetapi ia juga bertanggungjawab secara moral terhadap hasil pembelajaran itu. Untuk itu tugas dosen adalah pengajar sekaligus pendidik di bidangnya. Bahkan tugas pendidik PAUD harus dapat menjadi model bagi anak didiknya. Dalam kaitan itu pula maka pembelajaran yang dilakukan kepada mahasiswa PAUD, harus dapat mengembangkan semua aspek perkembangan. potensi anak secara optimal. Dengan kata lain tugas pendidik untuk mendidik guru tidak hanya berhenti pada mahasiswa tetapi bagaimana mahasiswa tersebut mampu mengimplementasikan ilmunya dalam mendidik anak usia dini. Karena itu tugas dosen sebagai pengajar merupakan suatu seni dan suatu ilmu. Pengajaran sebagai suatu seni artinya kreatif dalam bertindak, sementara itu sebagai sebuah ilmu pengajar harus mempunyai pengetahuan tentang 
mata ajar dan pemahaman yang kuat tentang prinsip-prinsip belajar dan pembelajaran.

Pengalaman pendidikan di Indonesia menunjukkan bahwa pemahaman pendidik dalam prinsip-prinsip belajar masih lemah. Secara nasional telah diakui bahwa kegagalan pendidikan di Indonesia disebabkan oleh pembelajaran yang terlalu berorientasi kognitif, sementara ranah afektif dan psikomotorik kurang memperoleh perhatian yang memadai. Akhirnya proporsi teori dan praktek dalam pembelajaran perlu menjadi perhatian yang serius. Apalagi aktivitas calon pendidik PAUD tidak hanya bertujuan untuk memperoleh pengetahuan bagi dirinya akan tetapi lebih dari itu bagaimana ilmu dan keterampilan yang diperoleh memampukan dirinya untuk dapat menyampaikan materi ajar kepada peserta didiknya kelak.

Salah satu mata kuliah yang sangat strategis dalam mengembangkan kemampuan guru tersebut adalah mata kuliah Media dan Tenologi. Mata Kuliah Media dan teknologi pembelajaran adalah disain, pengembangan, pemanfaatan, pengelolaan dan evaluasi sistem pesan berdasarkan strategi pembelajaran yang dikembangkan dengan mempertimbangkan karakteristik pembelajar, ketersediaan sumber daya serta permasalahan yang dihadapi dalam pembelajaran estetika dan ekpresi kreativitas, kesadaran lingkungan, perkembangan keterampilan motorik, numerik, bahasa dan Matematika, serta kesadaran diri dan kesadaran social sesuai dengan tingkat perkembangan anak. Penguasan mata kuliah media dan teknologi pembelajaran bertujuan untuk memampukan mahasiswa dalam membuat media dan teknologi yang digunakan dalam pembelajaran.

Sehubungan dengan itu maka Rancangan dan Penerapan Strategi Pembelajaran pada Mata Kuliah Media dan Teknologi Pembelajaran ini dapat mendorong efektivitas pembelajaran baik bagi peneliti sendiri maupun bagi mahasiswa PAUD.

\subsection{Permasalahan}

Pembelajaran merupakan suatu sistem yang saling berhubungan antara perencanaan, pelaksanaan dan evaluasi hasil belajar yang diikuti dengan penguasaan pengembangan secara teoretis dan praktis sekaligus. Untuk itu mahasiswa akan menemukan permasalahan pengembangan strategi pembelajaran sebagai berikut:
1) Pendekatan dan teori pembelajaran yang digunakan terkait dengan konten pembelajaran.

2) Pengembangan pembelajaran dalam kaitannya dengan proporsi teori dan praktek yaitu kognitif, afektif dan psikomotorik.

3) Pertimbangan dalam pengembangan pembelajaran dalam kaitannya dengan gaya belajar anak.

\subsection{Tujuan Penelitian}

Penelitian ini bertujuan:

1) Menemukan strategi pembelajaran yang efektif bagi mata kuliah media dan teknologi pembelajaran

2) Ajang pembelajaran bagi dosen dan mahasiswa dalam menemukan strategi belajar mengajar yang efektif dan efisien.

\subsection{Luaran yang Diharapkan}

Luaran yang diharapkan dari penelitian ini adalah:

1) Mahasiswa memahami keterkaitan satu mata kuliah dengan mata kuliah lainnya sebagai suatu kesatuan yang utuh dalam pelaksanaan tugas keguruan.

2) Mahasiswa dapat mengembangkan pembelajaran sesuai dengan gaya belajar anak.

3) Mahasiswa dan dosen dapat melakukan aktivitas yang saling membelajarkan dalam suatu aktvitas belajar di kelas.

4) Mahasiswa dapat menstruktur pengalaman belajar atas dasar teori pembelajaran yang kuat dan terstruktur dengan baik.

\subsection{Kegunaan Penelitian}

Program teaching grant ini berguna untuk:

1) Dosen Mata Kuliah Media dan Teknologi Pembelajaran dapat mengajar lebih efektif dan efisien.

2) Dosen, dosen pendamping dan mahasiswa saling membelajarkan dalam proses interaksi belajar mengajar yang dilakukan.

\section{KERANGKA TEORI / TINJAUAN PUSTAKA}

\subsection{Pengertian Belajar.}

Setiap mata kuliah mempunyai harapan yang sama dalam tujuan pengajarannya yaitu peserta didiknya menguasai tujuan pembelajaran yang telah direncanakan oleh dosen. Keberhasilan suatu proses 
belajar mengajar diukur dengan besaran prosentase penguasaan mahasiswa atas tujuan yang telah ditetapkan. Ukuran masing-masing dosen dalam membuat tujuan akan bervariasi pula sesuai dengan kualitas dosen dan kualitas pembelajaran yang dilakukan. Akhirnya kualitas pembelajaran tidak hanya ditentukan tujuan pembelajaran, lebih dari itu filosofi pembelajaran apa yang dianut oleh dosen dalam membuat tujuan pembelajaran. Filosofi pembelajaran akan berimplikasi kepada pendekatan, metodologi dan teknik pembelajaran yang dikembangkan dalam proses belajar mengajar.

Banyak ahli yang mengemukan pengertian belajar. Menurut Kimble, belajar adalah perubahan yang relatif permanen dalam potensi perilaku yang terjadi sebagai hasil latihan yang diperkuat. Hal yang sama juga dikemukakan oleh Gagne bahwa belajar perubahan dalam penguasaan atau kemampuan yang relatif menetap dalam jangka waktu tertentu. Perubahan seringkali terjadi dalam bentuk kemampuan pada kinerja tertentu. sikap, minat, atau nilai. Selanjutnya definisi belajar menurut Moore sebagai perubahan dalam suatu kapasitas individual dalam kinerjanya sebagai suatu hasil dari pengalaman (More, 2005:15). Perubahan perilaku sebagai mana yang dikemukakan ahli di atas ditentukan oleh pengalaman belajar yang terjadi dalam proses belajar mengajar sebagai implementasi dari tujuan pembelajaran yang dibuat oleh dosen sebagaimana yang dikemukakan di atas tadi.

\subsection{Pengembangan Pengalaman Belajar}

Pengembangan pengalaman belajar menurut Bloom dikategorikan ke dalam tiga ranah (domain belajar) yaitu ranah pikir (kognitif), ranah rasa (afeksi) dan ranah raga (psikomotorik). Ketiga ranah ini juga akan menentukan kualitas belajar sesuai dengan tingkatan penguasaan pada masingmasing ranah yang dikembangkan dalam tujuan pembelajaran. Pengalaman belajar yang dominan dilakukan dalam pendidikan di Indonesia selama ini lebih berorientasi kognitif, sementara pengalaman belajar afektif dan psikomtorik kurang mendapat perhatian. Untuk itu Anderson (2001:03) memandang pentingnya tujuan pembelajaran. Tujuan pembelajaran akan memfokuskan perhatian dan upaya untuk mencapai tujuan tersebut. Tujuan pembelajaran adalah suatu yang disengaja dan suatu tindakan dengan alasan tertentu.

Permasalahan belajar mengajar tidak hanya soal prosentase domain sebagaimana yang dikemukakan di atas, lebih dari itu pengintegrasian tujuan pembelajaran dengan perbedaan-perbedaan gaya belajar invidual masing-masing peserta didik tersebut. Pengintegrasian ini juga harus juga berarti belajar bagaimana belajar untuk tujuan belajar mandiri. Belajar mandiri artinya bahwa peserta didik tidak tergantung pada guru atau dosen sebagai satu-satunya sumber belajar bagi peserta didik. Menurut Moore (2005:11) lingkungan kelas yang direncanakan dengan baik apabila mahasiswa belajar bagaimana belajar. Hal ini sejalan dengan pembelajaran konstruktivisme yaitu guru harus fokus pada membangun konsep pemahaman mahasiswa sendiri

\subsection{Gaya Belajar}

Untuk membangun konsep pemahaman mahasiswa maka setiap dosen harus mamahami keunikan karakteristik mahasiswa. Karakteristik atau cara memproses informasi dalam pembelajaran ini disebut gaya belajar. Karakteristik memproses informasi ini berimpilkasi pada kecenderungan peserta didik dalam efektivitas suatu metode pembelajaran. Gaya belajar adalah semua cara yang diinginkan tentang belajar yang merupakan hasil dari variabel-variabel personal seperti psikologi, susunan kognitif, latar belakang sosial budaya dan pengalaman pendidikan. Sedangkan strategi belajar adalah proses mental yang digunakan anak untuk belajar (Nunan, 1991)

Gaya belajar juga menunjukkan kecenderungan mahasiswa dalam belajar. Gaya belajar (1) Visual: lebih suka, menyenangi atau menggunakan ilustrasi grafik, kode warna, peta, materi tertulis dan lain sebagainya; (2) Auditory: lebih suka, menyenangi atau menggunakan presentasi verbal seperti kuliah, diskusi kelompok, ceritera, musik dan lain sebagainya; dan (3) Kinestetik: lebih suka, menyenangi atau menggunakan gerakan. Kecenderungan dalam belajar secara visual, audio dan kinetetik ini berpengaruh terhadap efektivitas media yang akan digunakan. Ini disebut Bruner (1966) modus Belajar yaitu (1) pengalaman langsung (enactive); (2) pengalaman piktorial/ gambar (iconic); (3) pengalaman abstrak (symbolic).

Berdasarkan uraian di atas diketahui bahwa efektivitas strategi pembelajaran dipengaruhi oleh banyak faktor seperti minat, motivasi, sikap, perilaku dan gaya belajar mahasiswa. Semua itu menjadi bagian penting dalam menetapkan strategi belajar mengajar yang efektif. 


\subsection{Strategi Pembelajaran}

Pengembangan strategi pembelajaran dalam suatu proses belajar mengajar yang didasari oleh pengertian belajar merupakan pengembangan pengalaman belajar dengan mempertimbangkan gaya belajar mahasiswa. Untuk itu ada beberapa strategi utama yang dikembangkan dalam pemebalajaran yaitu metode pengajaran langsung, metode demontrasi, dan metode socratic.

Pertama, pengajaran Langsung sebagaimana yang dikemukakan oleh Moore (2005:227-229) pengajaran langsung Direct teaching disebut juga pengajaran sistematis atau pengajaran aktif, yaitu pengajaran yang berorientasi guru/dosen, model pengajaran membangun keterampilan (skill building instructional model) dimana guru memegang peran utama dalam pemberi informasi. Peran guru adalah mengemukakan fakta, aturanaturan atau urutan tindakan terhadap siswa sedapatnya dengan cara langsung. Pengajaran langsung ini berupa presentasi dengan format pemberian penjelasan (ceramah yang dimodifikasi) misalnya dengan memberi kesempatan kepada siswa untuk berlatih memberikan feedback. Format pengajaran langsung disebut juga interaksi antara guru dan murid yang melibatkan tanya jawab, mengulang dan memberikan latihan, serta mengoreksi kesalahan yang dilakukan oleh siswa.

Adapun langkah-langkah dalam pengajaran langsung adalah sebagai berikut:

1) Mengemukakan tujuan pembelajaran dan mengarahkan siswa terhadap materi pembelajaran. Menjelaskan kepada siswa apa yang akan dipelajari dan apa yang diharapkan dari mereka setelah belajar. Menjelaskan tujuan umum dan tujuan khusus pembelajaran. Mempersipkan mental atau sikap untuk kesiapan belajar bagi siswa.

2) Mereview prerequisite yaitu mengulang keterampilan atau konsep yang diperlukan untuk mempelajari pelajaran yang baru.

3) Menampilkan materi baru. Mengajar dengan mempresentasikan informasi, memberikan contoh konkrit yang bersifat variatif, mengemukakan konsep, dan sebagainya. Menunjukkan garis besar pengajaran apabila materi ajar bersifat kompleks.

4) Memberikan panduan praktis dan melaksanakan pendalaman pembelajaran. Memberikan pertanyaan kepada siswa guna mengukur tingkat pemahaman dan memperbaiki kesalahan konsepsi siswa.
Memberikan siswa pemecahan masalah praktis dan mengecek kesalahan konsepsi dan pemahaman. Menyuruh siswa menyimpulkan dengan kata-kata mereka sendiri. Menberikan pengajaran ulang apabila diperlukan.

5) Memberikan kesempatan untuk latihan mandiri. Siswa diberi kesempatan untuk mempraktekkan keterampilan baru atau menggunakan informasi baru dengan caranya sendiri, di tempat duduknya atau dalam kerjasama kelompok.

6) Mengukur kinerja dan memberikan feedback. Guru memberikan murid kerja praktek mandiri atau memberi kuis Memberikan feedback terhadap jawaban yang benar dan mengajar kembali keterampilan-keterampilan sesuai keperluan.

7) Memberikan kesempatan untuk berlatih langsung dan review. Guru memberikan pekerjaan rumah agar siswa dapat berlatih materi baru terlebih dahulu sebelum dijelaskan.

Kedua, Metode Demonstrasi sebagaimana yang dikemukakan oleh Moore (2005:259-261) bahwa metode demonstrasi adalah suatu metode dimana guru berdiri di depan kelas, mempertunjukkan sesuatu, dan kemudian menjelaskan apa yang sedang terjadi atau apa yang telah terjadi, atau bertanya kepada siswa apa yang telah terjadi. Suatu demonstrasi, merupakan proses pengajaran yang mempergunakan materi, display agar informasi dapat diperoleh oleh siswa. Walaupun hanya orang yang terlibat dengan materi adalah guru atau siswa yang melakukan demonstrasi, siswa menyukai demonstrasi karena mereka aktif terlibat dalam aktivitas belajar jika dibandingkan apabila siswa hanya bercerita tentang materi tersebut. Informasi dan konsep-konsep dimungkinkan dapat diakses oleh siswa, tergantung bagaimana keinginan siswa dalam belajar. Hal yang terbaik dari metode demonstrasi adalah meminta siswa melakukan demonstrasi, siswa yang melakukan demonstrasi ini lebih menumbuhkan minat dan keterlibatan siswa.

Dalam melaksanakan demonstrasi perlu mempertimbangkan panduan berikut ini:

1) Lakukan dengan lambat sehingga siswa dapat mengikutinya

2) Apabila prosedur bersifat kompleks, bagi demonstrasi ke dalam beberapa komponen kecil, kemudian sampai dilaksanakan secara keseluruhan.

3) Ulangi langkah-langkah demontarasi sampai siswa mengerti. 
4) Perlu diingat, reversed perhatikan bagian kiri dan kanan, jadi bentuklah demonstrasi sesuai dengan perspektif siswa.

Ketiga, Metode Socratic menurut Moore (2005:262) adalah suatu teknik yang menggunakan pertanyaan dan urutan interaksi yang didisain agar siswa didorong memberikan gambaran, daripada hanya sebagai pendengar. Metode ini lebih bersifat verbal dan interaktif. Sebagian besar guru menggunakan metode ini untuk mengembangkan informasi tentang konten. Secara umum siswa terlibat dalam pengajaran dengan cara mengajukan pertanyaan dan sekaligus melakukannya, mengarahkan siswa ke dalam suatu kontradiksi yang bersifat logis. Intinya, metode socratik mengikuti pola umum sebagai berikut ini:

1) Pertanyaan yang bersifat meluas dan buka tutup dimana sebagian siswa dapat menjawab pertanyaan pertama.

2) Urutan pertanyaan kedua mulai menyempit sesuai dengan respon dan terfokus pada pemikiran siswa terhadap topik dari strategi bertanya.

3) Menkaji ulang ceramah atau pertanyaan yang saling berkaitan interspersed guna menjaga keterkaitannya dengan poin sebelumnya.

4) Suatu pertanyanan menyimpulkan dan membawa siswa sesuai dengan akhir yang diharapkan.

\section{METODOLOGI PENELITIAN}

Metode penelitian yang digunakan adalah metode tindakan kelas. Menurut Mills (200:06) metode tindakan kelas adalah suatu temuan yang bersifat sistematik dalam suatu lingkungan belajar mengajar baik oleh guru atau stakeholder pendidikan lainnya yang guna mengumpulkan informasi tentang prosedur yang digunakan dalam suatu pembelajaran di sekolah yang bersangkutan. Informasi ini bertujuan untuk memperoleh gambaran, pegembangan refleksi praktis yang berpengaruh positif terhadap lingkungan sekolah, dalam meningkatkan hasil belajar mahasiswa.

Adapun langkah yang dilakukan dalam penelitian tindakan kelas ini adalah sebagai berikut:

1) Mengidentifikasi fokus area

2) Mengumpulkan data

3) Menganalisa dan menginterpretasi data

4) Mengembangkan suatu rencana tindakan

\section{HASIL DAN PEMBAHASAN}

Komponen yang akan dihasilkan:

\subsection{Desain dari Pengajaran (metode) dan Justifikasinya}

\subsubsection{Karakteristik Mata Kuliah Media dan Teknologi Pembelajaran}

Pengembangan pembelajaran media dan teknologi pembelajaran merupakan mata kuliah yang bersifat unik. Keunikan mata kuliah ini karena terkait dengan sub-sistem instruksional sebagai sebuah sistem pembelajaran yang saling berkaitan yaitu:

1) Identifikasi tujuan pembelajaran

2) Melaksanakan analisis instruksional

3) Mengidentifikasi karakteristik perilaku awal anak

4) Menulis tujuan pengajaran

5) Mengembangkan kriteria pengukuran

6) Pengembangan strategi instruksional

7) Pengembangan dan penyeleksian materimateri instruksional

8) Mendisain pelaksanaan evaluasi.

Permasalahan yang dihadapi mahasiswa semester 4 (empat) yang mempelajari mata kuliah ini mestinya telah menguasai pengembangan tujuan pembelajaran dalam mata kuliah kurikulum, karakteristik perkembangan anak dalam mata kuliah perkembangan anak usia dini atau praktek sesuai dengan perkembangan anak, kriteria pengukuran hasil belajar, dan penyeleksian materi. Pengembangan kurikulum PAUD diambil bersamaan dengan mata kuliah ini, sedangkan mata kuliah evaluasi belum dipelajari mahasiswa. Dengan demikian dalam pengajaran media dan teknologi pembelajaran, penjelasan penggunaan media dikaitkan dengan pengembangan materi dan cara pengukuran agar keberhasilan media dapat diketahui mahasiswa. Penjelasan secara umum tentang pengukuran ini dilakukan secara sekilas sehingga tidak terlalu menyita waktu pembelajaran media pembelajaran.

Kurikulum PAUD adalah kerangka yang terorganisir yang menggambarkan: (a) konten yang akan dipelajari anak, (b) proses yang akan dilalui anak guna mencapai tujuan kurikulum, (c) apa yang akan dilakukan guru dalam mencapai tujuan-tujuan tersebut, dan (d) konteks dimana belajar mengajar tersebut terjadi. Pelaksanaan kurikulum berorintasi aktivitas yang melibatkan anak dalam aktivitas pembelajaran/atau belajar sambil bermain secara konkrit. Untuk itu kurikulum 
harus mengembangkan pengalaman yang kaya dan sesuai perkembangan, Interaksi antara guru dan anak terjadi secara realitas, anak secara aktif terlibat dalam kegiatan "hands-on" yaitu anak menggunakan tangan lengan, kaki, dan badan, tidak hanya sekedar mendengar dan mengobservasi. Pengembangan kurikulum ini berimplikasi pada pengembangan metodologi pembelajaran.

Keunikan lainnya dalam pembelajaran Media dan Teknologi Pembelajaran adalah penguasaan teori harus diikuti dengan membuat media dan menggunakan media dalam aktivitas belajar. Aktivitas belajar dalam pengertian ini adalah mahasiswa dapat bentindak sebagai murid dan sebagai guru. Posisi mahasiswa sebagai murid berguna untuk memaknai aktivitas bagi murid, sedangkan posisi mahasiswa sebagai guru "observer" guna melihat efektivitas pembelajaran yang dilakukan oleh guru. Mahasiswa sebagai partisipan observer dan sekaligus melakukan evaluasi untuk perbaikan pembelajaran, utamanya terkait dengan media yang dikembangkan.

Beberapa hal yang perlu diketahui mahasiswa agar aktivitas pembelajaran dapat memenuhi kebutuhan anak maka pembelajaran harus memperhatikan bahwa (1) anak bersifat individual, yakni: (a) perkembangan anak seperti urutan perubahan dan pola perubahan, (b) tingkat keingintahuan yaitu cara anak berpartisipasi; (2) konsep anak secara utuh: kecenderungan untuk memperhatikan dan mendorong perkembangan anak dari segala aspek pertumbuhan seperti fisik, afektif dan aestetik, kognitif dan bahasa.

Untuk mempermudah dan menyederhanakan mengetahui area perkembangan bila dikategorikan dalam kelompok utama perkembangan fisik, sosial, emosional dan kognitif. Selanjutnya karena pengembangan pembelajaran Anak usia dini lebih bersifat aktivitas yang bersifat kongkrit maka mahasiswa perlu memahami Perkembangan Keterampilan. Suatu keterampilan perkembangan keterampilan adalah (1) suatu kemampuan yang berkembang dalam pergerakan badan, (2) kemampuan yang berkembang dalam perilaku sosialemosional, dan (3) kemampuan yang berkembang dalam pemikiran.

\subsubsection{Latar Belakang Mahasiswa}

Latar belakang mahasiswa yang beragam merupakan salah satu bahan dalam mempertimbangkan pendekatan aktivitas pembelajaran di kelas. Latar belakang mahasiswa yang berasal dari guru mempunyai kekuatan dalam praktek dalam penggunaan media pembelajaran, menguasai pengembangan kurikulum, dan kreativitas pengembangan belajar sambil bermain. Sementara itu mahasiswa murni belum mampu mengaitkan antara teori-teori mata pelajaran terkait lainnya kedalam suatu pemahaman pengembangan media pembelajaran.

Perbedaan latar belakang ini merupakan salah satu bahan pertimbangan pengelompokan mahasiswa dalam aktivitas pembelajaran baik yang bersifat teori maupun praktek. Pengelompokan mahasiswa yang dilakukan adalah dengan cara penempatan guru pada setiap kelompok belajar baik dalam berdiskusi maupun dalam aktivitas belajar sambil bermain yang di lakukan langsung di kelas.

Pengalaman guru dalam pembelajaran di sekolahnya masing-masing memperkaya aktivitas maupun diskusi diantara mahasiswa. Sedangkan ide-ide orisinil yang dikemukan oleh mahasiswa murni juga memberikan pembelajaran kepada guru yang penuh dengan rutinitas. Hal ini terlihat bahwa pengembangan pembelajaran guru sudah terpola sehingga aktivitas diskusi dari sudut keilmuan merupakan faktor penting dalam pembelajaran bagi mahasiswa yang berlatar belakang guru.

Tugas dosen dalam mata kuliah teknologi pembelajaran adalah bagaimana aktivitas yang dilakukan secara terstruktur yaitu aktivitas bermain yang dikembangkan dalam proses belajar merupakan aktivitas bertujuan sesuai dengan tujuan pembelajaran. Untuk itu dosen perlu menjelaskan landasan aktivitas tersebut dari sudut tujuan, pemilihan aktivitas yang dilakukan, dan refleksi terhadap aktivitas serta implikasinya terhadap pencapaian kurikulum.

\subsubsection{Teori}

Pada bagian awal pertemuan mata kuliah media dan teknologi pembelajaran lebih bersifat teoretis baik berkaitan dengan media maupun berkaitan dengan lintas mata kuliah seperti mata kuliah perkembangan, mata kuliah kurikulum dan mata kuliah evaluasi pembelajaran. Pemahaman mata kuliah sebagai suatu sistem pembelajaran merupakan bagian penting dalam pemahaman pembelajaran sebagai suatu sistem yang tidak terpisahkan.

Sehubungan dengan banyaknya mata kuliah yang terkait dengan mata kuliah teknologi pembelajaran, tentu tidak semua hal yang terkait itu dijelaskan 
secara terinci. Keterbatasan dalam penjelasan mata kuliah terkait tersebut dijadikan sebagai kekuatan untuk menjelaskan bahwa kurikulum merupakan tujuan yang ingin dicapai dijelaskan dalam tujuan instruksional khusus. Selanjunya tugas seorang guru adalah bagaimana tujuan instruksional khusus atau pencapaian indikator hasil belajar dapat dikembangkan dalam aktivitas yang dilakukan, misalnya apakah aktivitas tersebut mengembangkan satu atau beberapa perkembangan aspek pertumbuhan seperti fisik, afektif dan aestetik, kognitif dan bahasa. Untuk mempermudah dan menyederhanakan mengetahui area perkembangan bila dikategorikan dalam kelompok utama perkembangan fisik, sosial, emosional dan kognitif. Selanjutnya karena pengembangan pembelajaran Anak usia dini lebih bersifat aktivitas yang bersifat kongkrit maka mahasiswa perlu memahami perkembangan keterampilan. Suatu keterampilan perkembangan keterampilan adalah (1) suatu kemampuan yang berkembang dalam pergerakan badan, (2) kemampuan yang berkembang dalam perilaku sosialemosional, dan (3) kemampuan yang berkembang dalam pemikiran

\subsubsection{Praktek}

Pemahaman teori merupakan landasan dalam mengembangkan praktek pembelajaran. Perilaku pembelajaran merupakan implikasi dari penguasaan teori, maupun gaya belajar. Gaya belajar merupakan tata cara mahasiswa memproses informasi yang relatif menetap dalam proses belajar. Gaya belajar ini selanjutnya juga mempengaruhi cara mahasiswa dalam aktivitas belajar yang dikembangkan. Untuk itu dalam pelaksanaan praktek, teori merupakan informasi penting dalam menjelaskan aktivitas yang dilakukan. Penjelasan teori dapat dilakukan sebelum praktek dilakukan atau teori dapat dijelaskan bagaimana praktek yang telah dilaksanakan dijelaskan secara teori.

Praktek pengajaran merupakan aktivitas yang mempertemukan gaya belajar guru dan gaya belajar murid apabila mengajar nantinya. Untuk itu mahasiswa juga perlu diberi pemahaman tentang gaya belajar. Gaya belajat tersebut adalah (1) visual: lebih menyenangi atau menggunakan ilustrasi grafik, kode warna, peta, materi tertulis dan lain sebagainya; (2) auditory: lebih menyenangi atau menggunakan presentasi verbal seperti kuliah, diskusi kelompok, ceritera, musik dan lain sebagainya; dan (3) kinestetik: lebih menyenangi atau menggunakan gerakan. Disamping mempertimbangkan pengalaman belajar mulai dari yang konkrit sampai ke abstrak; pengalaman belajar mulai dari yang dekat sampai yang jauh; pengalaman belajar mulai dari yang mudah sampai yang sulit dari anak.

Disamping itu praktek mengajar bagi mahasiswa juga perlu mempertimbangkan prinsip pembelajaran anak usia dini yaitu: (1) berorientasi pada perkembangan anak; (2) berorientasi pada kebutuhan anak; (3) bermain sambil belajar atau belajar seraya bermain; (4) stimulasi terpadu; (5) lingkungan kondusif; (6) menggunakan pendekatan tematik; (7) aktif, kreatif, inovatif, efektif, dan menyenangkan; (8) menggunakan berbagai media dan sumber belajar; (9) mengembangkan kecakapan hidup; (10) pemanfaatan teknologi informasi; dan (11) pembelajaran bersifat demokratis.

\subsubsection{Pengembangan Satuan Pembelajaran}

Pengembangan Satuan pembelajaran mengacu kepada kebutuhan pembelajaran dengan mempertimbangkan karakteristik mata kuliah teknologi pembelajaran, latar belakang mahasiswa, teori, dan praktek pembelajaran. Untuk itu pembelajaran akan terbagi ke dalam tiga fase pertemuan: (1) pertemuan ke-1 sampai dengan pertemuan ke-6 fase teori, konsep dan media pembelajaran; dan (2) pembelajaran dikembangkan dalam dua tahapan masing-masing satu pertemuan konsep atau konten dan pengembangan pembelajaran dalam bentuk praktek langsung: (a) tahapan pertama satu pertemuan untuk persiapan konsep/konten dan persiapan media atau property yang akan digunakan, dan (b) pertemuan pada minggu berikutnya mahasiswa praktek langsung sesuai dengan suasana pembelajaran sesungguhnya.

\subsection{Indikator Pencapaian Tujuan dan Metode Pengukurannya.}

Soal UAS tahun ajaran 2008/2009 lebih bersifat teoretis dan implikasinya terhadap praktek pembelajaran dengan sistem ujian open book. Hal ini menguntungkan mahasiswa karena ia dapat menjelaskan pengalaman praktek dengan teori yang ada di buku. Walaupun dalam memberikan jawaban ujian harus dengan bahasa mahasiswa sendiri.

Soal UAS tahun ajaran 2009/2010 adalah penjelasan dari aktivitas yang tekah dilakukan dalam praktek. Umumnya perhatian mahasiswa terpecah dalam mengobservasi aktivitas kelompok 
lain, disamping mereka juga mempersiapkan diri untuk menampilkan aktivitas kelompoknya sendiri.

Rata-rata Nilai akhir yang menjadi kegiatan teaching grant atau semester Genap 2009/2010 lebih tinggi dengan nilai masing-masing indikator yang dinilai relatif sama. Hal ini menunjukan bahwa apabila aktivitas pembelajaran teknologi dan pembelajaran diikuti dengan aktivitas yang terstruktur berdasarkan teori yang ada maka kompetensi mahasiswa dalam pengembangan tuga, UTS, UAS dan nilai akhir akan lebih baik dan meningkat.

Untuk itu konten pembelajaran Teknologi Pembelajaran 2009/2010 adalah kesadaran diri dan kesadaran sosial, serta kesadaran lingkungan jauh lebih sedikit jika dibandingkan dengan konten pembelajaran Teknologi Pembelajaran 2008/2009 adalah Aestetics \& Creative Expression, Enviromental Awareness, Language and Literacy Development, Motor Skill and Development, Numeracy, Self and social awareness. Hal ini memudahkan proses pembelajaran yang berorientasi aktivitas. Aktivitas merupakan inti pembelajaran di PAUD dan pengalaman aktivitas langsung bagi mahasiswa PAUD penting untuk menghayati pembelajaran PAUD yang berintikan belajar seraya bermain

Tabel 1. Distribusi Pelaksanaan dan penilaian Mata Kuliah

\begin{tabular}{llcc}
\hline Aspek & Keterangan & $\begin{array}{c}\text { Semester } \\
\mathbf{2 0 0 8 / 2 0 0 9}\end{array}$ & $\begin{array}{c}\text { Semester } \\
\mathbf{2 0 0 9 / 2 0 1 0}\end{array}$ \\
\hline \multirow{2}{*}{ Mahasiswa } & Peserta & 18 & 25 \\
& Kehadiran & 80,51 & 94,23 \\
\hline \multirow{2}{*}{ Dosen } & Kehadiran & 14 & 16 \\
& Dosen & & 77,77 \\
\multirow{2}{*}{ Sistem } & Tugas & 79,33 & 77,50 \\
Penilaian & UTS & 84,20 & 78,48 \\
& UAS & 78,56 & 78,05 \\
& Nilai Akhir & 73,39 & \\
& Angka & & \\
\hline & & & \\
\hline & & & \\
& & &
\end{tabular}

\section{KESIMPULAN}

Berdasarkan temuan hasil penelitian tindakan kelas yang dilakukan dalam mata kuliah Teknologi dan media pembelajaran, maka dapat dismpulkan hal sebagai berikut:

1) Strategi pembelajaran yang efektif bagi mata kuliah media dan teknologi permbelajaran perlu diperkuat dengan aktivitas yang melibatkan mahasiswa secara langsung sebagaimana anak usia dini belajar sehingga calon guru dapat menghayati kegiatan yang dilakukan anak nantinya.

2) Pengelompokan mahasiswa yang telah mengajar dapat memperkuat inspirasi dan meningkatkan kreativitas mahasiswa murni dalam melakukan aktivitas pembelajaran di kelas.

3) Diskusi setelah aktivitas merupakan wahana yang konstruktif pembelajaran bagi dosen dan mahasiswa dalam menemukan strategi belajar mengajar yang efektif dan efisien.

Berdasarkan hasil penelitian dan kesimpulan yang dikemukakan sebelumnya maka dapat disarankan hal sebagai berikut:

1) Mata kuliah teknologi dan media pembelajaran merupakan sub-system pembelajaran secara keseluruhan. Untuk itu pemahaman kegiatan atau aktivitas mata kuliah ini harus dikaitkan dengan system instruksional yang lebih luas seperti perencanaan pembelajaran, kurikulum, strategi belajar mengajar dan evaluasi.

2) Aktivitas yang dilakukan mahasiswa merupakan inti dari kegiatan PAUD yang bersifat holistik, terintegrasi dan terkadang bersifat serta merta atau emergen. Untuk itu aktivitas bermain harus terstruktur sesuai dengan tujuan pembelajaran yang telah ditetapkan.

3) Aktivitas yang dikembangkan harus berorientasi kepada perkembangan dan kebutuhan anak. Untuk itu pembelajaran yang dikembangkan harus bersifat kongkrit dan melibatkan seluruh indera anak dengan cara melbatkan anak secara langsung. 


\section{DAFTAR ACUAN / PUSTAKA}

[1] Anderson, Lorin W. dan David R. Krathwoh, A Taxonomy for Learning Teaching and Assessing: A Revision of Bloom's Taxonomy of Educational Objectives A Bridged Edition, New York: Longman, 2001.

[2] Mills, Geofrey E., Action Reserch: A Guide for the Teacher Researcher New Jersey:Merill and Imprint of Prentice Hall, 2000.

[3] More, Kenneth D., Effective Instructional Strategies: From Theory to Practice (London: Sage Publication Inc., 2005.
[4] Nurturing Early Learner, Book 1 Framework, Singapore: Minsittry of Education, 2003.

[5] Nurturing Early Learner, Book 2 Putting Principle into Practice, Singapore: Ministery of Education, 2003.

[6] Nurturing Early Learner, Book 4 Enviromental Awareness, Singapore: Ministery of Education, 2003.

[7] Nurturing Early Learner, Book 8 : Self and social awareness, Singapore: Ministery of Education, 2003. 